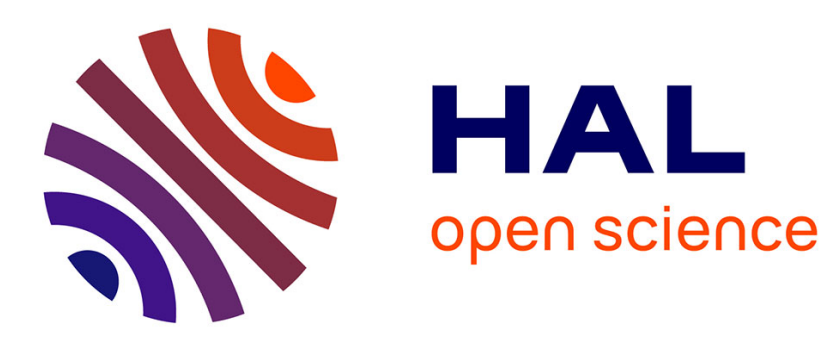

\title{
The Right to Land and Territory: New Human Right and Collective Action Frame \\ Priscilla Claeys
}

\section{To cite this version:}

Priscilla Claeys. The Right to Land and Territory: New Human Right and Collective Action Frame. 2016. halshs-01316857

\author{
HAL Id: halshs-01316857 \\ https://shs.hal.science/halshs-01316857 \\ Preprint submitted on 17 May 2016
}

HAL is a multi-disciplinary open access archive for the deposit and dissemination of scientific research documents, whether they are published or not. The documents may come from teaching and research institutions in France or abroad, or from public or private research centers.
L'archive ouverte pluridisciplinaire HAL, est destinée au dépôt et à la diffusion de documents scientifiques de niveau recherche, publiés ou non, émanant des établissements d'enseignement et de recherche français ou étrangers, des laboratoires publics ou privés. 


\section{The Right to Land and Territory : New Human Right and Collective Action Frame}

Priscilla Claeys

N¹09 | mars 2016

Resistance against the appropriation of nature, especially land, has been one of the key struggles of the transnational agrarian movement $\mathrm{La}$ Via Campesina (LVC) since its inception in 1993. The issue of access to land has become even more central after the food crisis of 2007-08, in a context increasingly marked by land grabbing and climate change. This contribution addresses one of the most significant dimensions of the contemporary agrarian question - i.e. access to and control over land and natural resources-, through a critical examination of the emergence of the "right to land and territory", both as a collective action frame deployed by transnational peasant movements, and as a new human right in international law. 


\title{
The Right to Land and Territory : New Human Right and Collective Action Frame
}

\author{
Priscilla Claeys
}

Mars 2016

\section{The author}

Priscilla Claeys received her PhD in Political and Social Sciences from the University of Louvain (UCL) in 2013 and is now a Postdoctoral researcher. Priscilla worked as an Advisor to the UN Special Rapporteur on the right to food from 2008 to 2014. She previously worked for a number of human rights organizations and development NGOs. Her research interests include transnational agrarian movements, human rights, food sovereignty, the right to food, alternative food economies and the ecological transition.

\section{The text}

The ideas expressed in this article were first presented at the international Symposium "Property from Below" which was held at MIT on 28 February 2014 and co-organized by Balakrishnan Rajagopal and Olivier De Schutter. An earlier version of this paper benefited from comments by Laura Silva-Castañeda and Deborah Delgado-Pugley, and was published in French under "Droit à la terre et contrôle des territoires. Du rôle du droit dans les luttes agraires", in Silva-Castañeda Laura et al (eds.) Au-delà de l'accaparement. Dynamiques d'exclusion et nouvelles stratégies d'accès à la terre. (Peter Lang, 2014).

The research leading to these results has received funding from the European Union's Seventh Framework Programme (FP7/2007-2013 - MSCA-COFUND) under grant agreement n²45743 - Post-doctoral programme Braudel-IFER-FMSH, in collaboration with the Collège d'études mondiales (FMSH).

\section{Citing this document}

Priscilla Claeys, The Right to Land and Territory : New Human Right and Collective Action Frame, FMSHWP-2016-109, mars 2016.

(C) Fondation Maison des sciences de l'homme - 2015

Informations et soumission des textes :

wpfmsh@msh-paris.fr

Fondation Maison des sciences de l'homme 190-196 avenue de France

75013 Paris - France

http://www.fmsh.fr http://halshs.archives-ouvertes.fr/FMSH-WP http://wpfmsh.hypotheses.org
Les Working Papers et les Position Papers de la Fondation Maison des sciences de l'homme ont pour objectif la diffusion ouverte des travaux en train de se faire dans le cadre des diverses activités scientifiques de la Fondation : Le Collège d'études mondiales, Bourses Fernand Braudel-IFER, Programmes scientifiques, hébergement à la Maison Suger, Séminaires et Centres associés, Directeurs d'études associés..

Les opinions exprimées dans cet article n'engagent que leur auteur et ne reflètent pas nécessairement les positions institutionnelles de la Fondation MSH.
The Working Papers and Position Papers of the FMSH are produced in the course of the scientific activities of the FMSH: the chairs of the Institute for Global Studies, Fernand Braudel-IFER grants, the Foundation's scientific programmes, or the scholars hosted at the Maison Suger or as associate research directors. Working Papers may also be produced in partnership with affiliated institutions.

The views expressed in this paper are the author's own and do not necessarily reflect institutional positions from the Foundation $\mathrm{MSH}$. 


\section{Abstract}

Resistance against the appropriation of nature, especially land, has been one of the key struggles of the transnational agrarian movement La Via Campesina (LVC) since its inception in 1993. The issue of access to land has become even more central after the food crisis of 2007-08, in a context increasingly marked by land grabbing and climate change. This contribution addresses one of the most significant dimensions of the contemporary agrarian question - i.e. access to and control over land and natural resources -, through a critical examination of the emergence of the "right to land and territory", both as a collective action frame deployed by transnational peasant movements, and as a new human right in international law. After describing how LVC activists have used the human rights framework to formulate land claims (II), this article discusses a number of tensions that underlie the recognition and protection of land rights, either through institutional channels ("from above")(III), or through the defense and control of lands and territories ("from below")(IV). It ends with a discussion of the various frames that are deployed by La Via Campesina activists in ongoing land struggles, and of the possible impact of institutional progress on these struggles.

\section{Keywords}

human rights, land, territory, peasant movements, food sovereignty, framing

\section{Le droit à la terre et au territoire : nouveau droit humain et cadre d'action collective}

\section{Résumé}

La lutte contre l'appropriation de la nature, en particulier la terre, a été l'une des luttes clés du mouvement agraire transnational La Via Campesina (LVC) depuis sa création en 1993. La question de l'accès à la terre est devenue encore plus centrale après la crise alimentaire de 2007-08, dans un contexte de plus en plus marqué par l'accaparement des terres et le changement climatique. Cet article traite de l'une des dimensions les plus importantes de la question agraire contemporaine - l'accès à et le contrôle des territoires et ressources naturelles-, en proposant un examen critique de l'émergence du "droit à la terre et au territoire ", à la fois comme cadre d'action collective déployé par les mouvements paysans transnationaux, et comme nouveau droit humain en droit international. Après avoir décrit comment le cadre des droits humains a été utilisé par les activistes du mouvement LVC pour formuler leurs revendications sur la terre, cet article discute un certain nombre de tensions qui sous-tendent la reconnaissance et la protection des droits à la terre, soit par les canaux institutionnels (" par le haut »), soit par la défense et le contrôle des terres et des territoires ("par le bas »). Il se termine par une discussion des divers cadres qui sont actuellement déployés par les militants de LVC dans les luttes foncières et de l'impact possible des progrès institutionnels sur ces luttes.

\section{Mots-clefs}

droits humains, terre, territoire, mouvements paysans, souveraineté alimentaire, cadrage 


\section{Sommaire}

Introduction

La Via Campesina, Land Struggles and Human Rights Framing

Institutional Strategies to Demand New (Land) Rights at the International Level

The Declaration on the Rights of Peasants at the Human Rights Council 10

Land Issues at the Committee on World Food Security

Towards a Right to Land and Territory in International Law?

Non-Institutional Strategies: the Defense of Lands and Territories

Reclaiming Control over Lands and Territories

Which Reference Frame for Future Land Struggles?

References 


\section{Introduction}

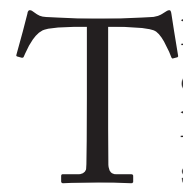

he commodification of natural resources, and especially the conversion of land into a product that can be bought, sold, leased or exchanged on markets, is one of the founding characteristics of capitalism (Bernstein 2010, 23). Marx and Polanyi, for example, showed that the enclosure of land played a key role in the development of capitalism in England in the 16th and 17th century (Vergara-Camus 2012, 1153). Today, an increasing proportion of the common resources upon which rural communities depend, such as grazing lands, wetlands and woodlands, are being commoditized (High Level Panel of Experts on Food Security and Nutrition (HLPE) 2011, 27). This historical process of commodification is far from complete however : in many parts of the world, the establishment of private property rights on the land, enshrined in law and enforced by the state, is not yet a reality. It is challenged by social actors, particularly in the rural South (Bernstein 2010, 98-102), but also in the North (Transnational Institute 2013).

The privatization of resources is closely linked to two other processes typical of capitalism: the failure to take into account social and environmental externalities, and the rapid exploitation of presumably unlimited natural resources, leading to growing social inequalities and an unprecedented ecological crisis. The pressures on the land seem more numerous every day, as the result of urbanization, tourism, industrialization or mining. The privatization of the environment, characteristic of the "green economy" (Fairhead, Leach, and Scoones 2012) is now recommended as the most effective way to ensure the preservation of resources. Moreover, land has been transformed into an opportunity for transnational investment, as shown by the growing number of large-scale acquisitions of land, a phenomenon widely documented since the 2007-08 food crisis and reinforced by the financialization of agriculture (Vía Campesina and GRAIN 2009 ; De Schutter 2011 ; Margulis, McKeon, and Borras 2013). States have played an active role in this process, often facilitating the appropriation of nature through legislative reforms to encourage companies, pension funds and other states to invest in land (Künnemann and Monsalve Suárez 2013, 129).
The gradual appropriation of nature has had devastating consequences for the rural world, and was flatly rejected by many peasant movements. At the heart of the global food crisis of 20072008, the transnational agrarian movement La Via Campesina denounced :

" the ferocious offensive of capital and of transnational corporations (TNCs) to take over land and natural assets (water, forests, minerals, biodiversity, land, etc.), that translates into a privatizing war to steal the territories and assets of peasants and indigenous peoples"

(Vía Campesina 2008c).

Resistance against the appropriation of nature, especially land, has been at the center of La Via Campesina's struggles since its inception in 1993. One of the objectives of food sovereignty, the movement's principal demand, is to ensure that the rights to use and manage lands, territories, waters, seeds, livestock and biodiversity are in the hands of those of us who produce food (Monsalve Suárez 2012).

This contribution addresses one of the most pressing dimensions of the agrarian question today "who will control and how will they control the resources necessary to sustain life ?" (VergaraCamus 2012,1134) - , through a critical examination of the emergence of the "right to land and territory", both as a collective action frame deployed by transnational peasant movements, and as a new human right in international law. Building on Polanyi and Wood, Vergara-Camus convincingly argues that the establishment of "absolute private property rights" over land, enabled by the separation of the economic from the political that is emblematic of neoliberal globalization, represents a crucial element in this expansion of the logic of capital, for it is the physical basis for any type of natural resource exploitation. From this perspective, agrarian struggles for the "right to land", broadly speaking, can usefully be analyzed as attempts to re-establish "political limits on access to, and exploitation of, land and resources" (Vergara-Camus, 2012 1137).

This contribution integrates insights from the sociology of rights, sociology of social movements and rural sociology. It is based on more than 115 semi-directed interviews of leaders and members of the transnational food sovereignty movement, and notably with La Via Campesina activists in Mexico, Guatemala, Nicaragua, Canada, France, 
Belgium and Indonesia, and on participant observation at more than 65 meetings with agrarian activists in the above mentioned countries as well as in Haiti, Nepal, India, the Democratic Republic of the Congo, Bolivia and various UN bodies, notably the Committee on World Food Security (CFS) and the Human Rights Council (HRC), between April 2008 and November 2014.

After describing how the human rights framework has been used by La Via Campesina (LVC) activists to formulate land claims (II), this article discusses a number of tensions that underlie the recognition and protection of land rights, either through institutional channels ("from above") (III), or through the defense and control of lands and territories ("from below")(IV). It ends with a discussion of the various frames that are currently deployed by La Via Campesina activists in ongoing land struggles.

\section{La Via Campesina, Land Struggles and Human Rights Framing}

The transnational social movement La Via Campesina counts more than 164 national and sub-national organizations from 79 different countries, as of the last International Conference of June 2013. It developed in the early 1990s as farmers from various organizations from Central and South America, North America, Asia and Europe started sharing experiences and set to create a network to articulate a common response to the wave of neoliberal reforms that had struck their regions in the 1980s, leading to a drastic decline in their livelihoods (Desmarais 2008 ; P. Rosset and Martinez 2010). Over the last twenty years, LVC activists have mobilized around a range of issues including agricultural trade liberalization and the World Trade Organization (WTO), genetically modified organisms (GMOs), agrarian reform, and development projects (dams, mining concessions, nature reserves), strongly contributing to the visibility of the global justice movement (Pleyers 2010). More recently, LVC has turned its attention to issues of climate justice (Bullard and Müller 2012), agroecology (Rosset 2011), land and resource grabbing, and the articulation of all three.

Access to land was a key theme of the parallel forum to the World Food Summit in 1996 (Vía Campesina 1996) which saw the participation of several La Via Campesina activists. In 1999, La Via Campesina (LVC) launched the "Global Campaign for Agrarian Reform" (GCAR), in partnership with the international human rights organization FIAN that defends and promotes the right to adequate food worldwide. The GCAR denounced the land titling policies of the World Bank and its "market assisted land reform" programmes for privatizing land and leading to the reconcentration of the land. On the occasion of the WTO ministerial of Seattle, the same year, the network called for the right of each country to "prohibit imports in order to protect domestic production and to implement Agrarian Reform providing peasants and small to medium-sized producers with access to land" (Vía Campesina 1999). In the years following, LVC engaged in dialogue with other constituencies - nomadic pastoralists, fisher folk and indigenous peoples on the various meanings and functions attached to the land, for example at the occasion of the 'Land, territory and dignity' Forum organized in the margins of the 2006 International Conference on Agrarian Reform and Rural Development (ICARRD) (Rosset 2013, 724). It also tried to define its own vision of agrarian reform, integrating lessons learned from past agrarian reform processes, and linking the land issue to the broader issues of food sovereignty and the environment (Borras 2008).

The issue of access to land has become even more central after the food crisis of 2007-08, in a context increasingly marked by land grabbing and climate change. Gathered at the occasion of the World Summit on Food Security organized by FAO in June 2008, La Via Campesina and other social organizations and movements, demanded that an end be put to the "new enclosure movement" that converts "arable, pastoral, and forest lands for the production of fuel" (International Planning Committee for Food Sovereignty (IPC) 2008). As anticipated by Borras, the major policy battle around land policy issues today is being fought around the double issue of "formalization" of land rights and "privatization" of remaining public lands (Borras 2008, 281). The terms of the global land reform debates have radically changed, forcing La Via Campesina to think beyond land reform, and the GCAR to reassess its strategy. This, in essence, was the objective of the International Workshop and Seminar "Agrarian Reform and Defense of Land and Territory in the 21st Century : The Challenge and the Future" 
organized by the movement in Indonesia in 2012 (Vía Campesina 2012). At the heart of the discussions were the need to expand the scope of the GCAR to better take into account the issue of access to land in the North, the specific challenges faced by indigenous peoples in the defence of their territories, and how to react to resource grabbing and counter-agrarian reform processes.

To build a common agenda for a widely diverse (politically, economically and culturally) membership, and to overcome North-South divisions, La Via Campesina has widely relied on human rights "framing". The movement has framed its main organizational frame, food sovereignty as a new collective right (Claeys 2012b, 844-845) - the right of peoples "to define their own food and agriculture systems" (Nyéléni Food Sovereignty Forum 2007b) - and, to a large extent, has framed its struggles over access to land and control over resources as human rights issues. Framing - the production of "meaning" for participants and their opponents - is of the main activities of social movements: it is used to diagnose certain situations as problematic, propose solutions and call activists to action. The "rights master frame"1 (Benford and Snow 2000, 619) has been mobilized by a wide range of movements, for it facilitates the international exportation of claims (Agrikoliansky 2010, 232) and helps formulate demands in a way that does not put forward particular or sectorial interests (Mooney and Hunt 1996, 179). These factors help explain the appeal of the rights master frame for La Via Campesina activists, who faced the challenge of having to articulate demands emerging from widely different local, cultural, political and social contexts.

Human rights framing was at the core of the "Global Campaign for Agrarian Reform" (GCAR) launched in 1999². La Via Campe-

1. If most frames are "organizational" or specific to a particular social movement, some frames are shared by a large number of movements, because they are more inclusive, more flexible, and because they "resonate". This allows them to function as "master frames" (RD Benford and Snow, 2000, 611, 618). The "rights master" frame was initially mobilized by the civil rights movement (McAdam 1990 ; Valocchi 1996), and has been deployed in many social struggles articulated in terms of rights: welfare rights (Reese and Newcombe 2003), women's rights, the rights of migrants (Elias 2010), gay and lesbian rights (Hull 2001; Plummer 2006), indigenous rights (Sieder 2011 ; Idrus 2010).

2. An assessment of the achievements and limitations of the GCAR is beyond the scope of this paper. Such an assessment was conducted by Borras, who showed sina and FIAN International jointly framed land claims in terms of rights, in an effort to articulate agrarian issues and human rights law and methodologies, and provide the campaign with a resonant master frame (Borras 2008, 265). Exchanges between the two networks led, in the first years of the campaign, to the collective elaboration of what could be described as a "right to agrarian reform" frame, although the term was never formally used. Efforts to give life and content to this right soon revealed important differences in how the two networks conceived of human rights. For La Via Campesina, the objective of the GCAR was to defend the right to produce, to resist the creation of land markets by the World Bank, to denounce the commodification of land, to demand recognition of the social function of the land, and to preserve/promote collective forms of land use/tenure (Vía Campesina 2006). For FIAN International, which had documented numerous land conflicts since its creation in 1986, and had supported local communities in their struggle for the land, mostly through letter campaigns, the challenge was twofold. It was, first, to emphasize that excluding food producers from accessing the productive resources that they rely on was a human rights violation, and, second, to conceptualize the implementation of redistributive land reforms as an obligation of states (Windfuhr 2000).

From a legal perspective, these two objectives pointed to two distinct (but complementary) state obligations : respect and fulfil. The obligation to respect requires states not to take any measures that would result in preventing individuals from having access to adequate food, recognizing that the right to food is primarily to be realized by right holders themselves through their economic and other activities, which states have a duty not to interfere with. The obligation to fulfil, in turn, requires states to adopt measures aimed at improving right-holders' access to and utilisation of resources and means to ensure their livelihood, such as land reform (Committee

that five factors played a role in enabling the emergence of the GCAR - a swift externalization of national issues (mainly from Brazil, Central America, the Philippines and South Africa), the emergence of allies with political and logistical resources, forging of a common meaning in the campaign and the emergence of the World Bank as common target, faster and cheaper cross-border communication and transportation, and the attainment of greater degree of autonomy and capacity to combine forms of collective actions - (S. M. Borras 2008). 
on ESCR 1999). Yet, from a framing perspective, these two objectives were somewhat in tension and their articulation was no easy task.

To highlight the importance of securing access to land to ensure the livelihood of rural communities (Künnemann and Monsalve Suárez 2013, 123), FIAN deployed a "right to feed oneself" frame (Künnemann 1984, 95), in particular in its communications to the general public and potential allies. This frame aimed at pushing for an "agrarian" interpretation of the right to food, and at clarifying that the right to food was not to be understood as the right to be fed. In its communications to states, however, FIAN always made explicit reference to the right to food as recognized by the UN, and almost systematically recalled the obligations that derived from the International Covenant on Economic, Social and Cultural Rights (ICESCR). The "right to food" frame enabled the organization to remind states of their commitments under international human rights law, and imbued the demands it made of states with the legitimacy of internationally agreed language.

This strategy proved partly successful, as it allowed FIAN to use the law to push for a progressive interpretation of it $^{3}$. Thanks to its "right to feed oneself" frame, for example, FIAN managed to influence normative developments of the right to food in ways that recognize its agrarian dimensions ${ }^{4}$. At the same time, the "right to feed oneself" frame can be considered as a "failed frame" (Heitlinger 1996), in the sense that it lacked resonance. It was brought to the attention of $\mathrm{La} \mathrm{Via}$ Campesina organizations in the early 90s, but was, interestingly, not picked up by LVC activists, despite its striking proximity with the then emerging "right to food sovereignty" frame. It was later

3. This is exemplified by article 11(2) of the ICESCR, which was used by FIAN activists to justify the existence of an obligation to implement agrarian reforms: "the States Parties to the present Covenant [...] shall take $[. .$.$] the measures [. .$.$] which are needed [.$.$] to$ improve methods of production, conservation and distribution of food by making full use of technical and scientific knowledge, by disseminating knowledge of the principles of nutrition and by developing or reforming agrarian systems in such a way as to achieve the most efficient development and utilisation of natural resources $[\ldots . .$. ".

4. General comment 12 defines availability as "the possibilities either for feeding oneself directly from productive land or other natural resources, or for well functioning distribution, processing and market systems that can move food from the site of production to where it is needed in accordance with demand" (Committee on ESCR 1999). abandoned by the organization, in favour of the more universal "right to food" frame, which was perceived as able to better capture the nutritional dimensions of the right to food, and the specific needs of the urban poor. The former Secretary General of FIAN comments: "You cannot replace the right to food by the right to feed oneself (...) Vía Campesina uses the point of view of producers (...) but they do not see themselves as having to solve this (...) the right to feed oneself was dropped from FIAN's vision and documents."

While FIAN defended access to land as an essential component of the human right to food, La Via Campesina did not confine its claims to the limits set by international human rights law. Rather, it framed its demands in terms of rights that did not enjoy legal recognition and were in that sense new, such as the "right to produce", the right "to be a peasant", and the "right to land and territory". Such claims indicated a departure from the social-democratic conception of rights (Stammers 1995, 488) that is at the heart of the right to food, and indicated the emergence of an alternative conception of human rights, characterized by a strong focus on the concept of responsibility and an emphasis on the interdependence of human beings and nature/their environment (Claeys 2012a). This excerpt from the synthesis report of the Nyeleni 2011 Food sovereignty European Forum is illustrative of this :

"Reclaiming the right to our Commons. We oppose and struggle against the commodification, financialisation and patenting of our commons, such as : land ; farmers', traditional and reproducible seeds ; livestock breeds and fish stocks ; trees and forests ; water ; the atmosphere; and knowledge. Access to these should not be determined by markets and money. In using common resources, we must ensure the realisation of human rights and gender equality, and that society as a whole benefits. We also acknowledge our responsibility to use our Commons sustainably, while respecting the rights of mother earth. Our Commons should be managed through collective, democratic and community control"

(Nyéléni Food Sovereignty Forum 2007a).

5. Interview, 23 June 2009. 


\section{Institutional Strategies to Demand New (Land) Rights at the International Level}

La Via Campesina has sought recognition of new human rights dealing with access to land and resources in two international arenas : the Human Rights Council (HRC) of the United Nations, where La Via Campesina has obtained, with the support of human rights experts, that negotiations take place on a "Declaration on the Rights of Peasants and Other People Living in Rural Areas", and the Committee on World Food Security (CFS), where discussions have taken place on how to best secure tenure of land, how to support reinvestment in small-holder agriculture, and how to regulate large-scale acquisitions of land. Elsewhere, I have discussed the institutional trajectory of the right to food sovereignty, with an emphasis on international trade and the right to participate in policy-making (Claeys 2012b). This contribution focuses on the "right of peoples to land and territory" (Vía Campesina 2012), leaving aside other important developments with regard to rights and resources, such as the recognition of "farmers' rights" over their seeds at the FAO through the International Treaty on Plant Genetic Resources for Food and Agriculture (Batta Bjørnstad 2004 ; GRAIN 2005).

One could wonder why La Via Campesina has put efforts into the creation of new human rights, when existing human rights are widely perceived by activists as both difficult to realize and almost impossible to enforce. Why not focus on implementation? Why not make (better) use of national, regional and international human rights protection mechanisms? For years, this very issue was at the heart of tensions between La Via Campesina activists and human rights experts, together with the fact that the "proliferation" of new rights was perceived by the human rights community as a threat to the consistency of the existing human rights framework (Alston 1984).

In this contribution, I defend the idea that processes led by peasant movements to achieve the recognition of new human rights at the international level (Bob 2010) are relevant insofar as they allow for "new interpretations and reconfigurations of meanings" to emerge (Idrus 2010,

6. Interview, 3 July 2009.
91) and provide an arena where contestation can take place. Such processes are also indicative of the ability of contemporary transnational agrarian movements to create "legal opportunity structures" understood as a specific set of circumstances allowing a social movement to push through legal change (Israël 2003), in this case at the UN. The creation/seizing of such opportunities is important to analyze in view of what local and national peasant movements may experience or perceive as their inability to bring social/legal change in national settings. Failure to achieve the enforcement of state laws is often what drives activists to go global (Nash 2012, 806). Conversely, peasant activists may decide to support international processes because they expect that these will help achieve goals set at the national level ${ }^{7}$, such as agrarian reform (Konsorsium Pembaruan Agraria KPA 2013). For all these reasons, engagement in intergovernmental processes is often characterized by a tension between the demand to be included as citizens (legal inclusion) and resistance against the state, a tension that has been well documented in the case of indigenous peoples' rights (Idrus 2010).

By engaging in the very definition of human rights, peasant movements call for an inclusive public deliberation on the future of the peasantry and the allocation of natural resources. In so doing, they insist that the value of human rights lies not in their supposed universality but in their very contestability : only through global public dialogue can we make sure human rights are relevant, and can be considered universal ${ }^{8}$ (Whiteside and Mah 2012, 924). They also remind us that, if the contribution of epistemologies from the South is crucial to the reconfiguration of human rights "from below" (Rajagopal 2003 ; Santos and Rodríguez-Garavito 2005), such a reconfiguration needs to account for ongoing social struggles over rights and resources (Newell and Wheeler 2006).

7. This effect has been described by Keck and Sikkink as the "boomerang" pattern of influence: domestic NGOs bypass their state and search out international allies to try to bring pressure on their states from outside (Keck and Sikkink 1998). While research conducted by Keck and Sikkink focuses on transnational advocacy networks and the impacts of transnational campaigns on the domestic context, many parallels can be drawn with the expected outcomes of engaging in norm-setting at the international level.

8. Human rights have claims to universality only if they survive public scrutiny and discussion (Amartya Sen cited in Whiteside and Mah 2012, 924). 
The Declaration on the Rights of Peasants at the Human Rights Council

The Declaration on the Rights of Peasants (Vía Campesina 2008a), adopted by the International Conference of Maputo in 2008, places a strong emphasis on land issues. Article 4 on the "right to land and territory", claims a wide range of new rights for peasants, such as :

- the "right to own land, collectively or individually, for their housing and farming";

- the "right to toil on their own land, and to produce agricultural products, to rear livestock, to hunt and gather, and to fish in their territories";

- the right to "toil and own the non-productive state land on which they depend for their livelihood";

- the right to "manage, conserve and benefit from the forests";

- the right to "reject all forms of acquisitions of land and land conversion for economic purposes"; and

- the "right to security of tenure and not to be forcibly evicted from their lands and territories" (Vía Campesina 2008a).

The Declaration on the Rights of Peasants is the result of seven years of internal discussions and a long process of development and consultation. The first version was developed in 1999 in Indonesia. The Peasants' Rights Charter, as it was then called, was originally discussed by farmers of 24 provinces, academics and NGO activists, in the framework of a participatory research project on integrated pest management conducted by the International Institute for Environment and Development (IIED) in the second half of the 1990s. At the time, the main concern of farmers was to denounce the green revolution and corporate take-over of agriculture (Fakih, Rahardjo, and Pimbert 2003,28), but land issues were also at the forefront. Despite the violent repression endured during the Suharto regime (1967-1998), land struggles took place without interruption in rural Indonesia and became even more prominent after the fall of Suharto, with the support of student movements and urban activists (Bachriadi 2009, 1-6). In 2002, the Indonesian agrarian organization SPI brought the draft Declaration to the attention of the other member organizations of La Via Campesina in the region (Vía Campesina
Regional South East Asia and East Asia 2002). The Declaration was later put on the agenda of the international working committee of La Via Campesina on human rights, and successive versions were submitted for discussion throughout the network.

In recent years, La Via Campesina has actively worked to bring the Declaration to the Human Rights Council of the United Nations (Vía Campesina 2008b), with the support of human rights experts and NGOs such as FIAN International and Centre Europe Tiers Monde (CETIM). These efforts have borne fruit. On 23 September 2012, the Council adopted a resolution on the "Promotion of the human rights of peasants and other people living in rural areas" (A/HRC/21/L.23) sponsored by Bolivia, Cuba and South Africa. An inter-governmental working group was created with the mission to negotiate, finalize and submit to the Council a final draft Declaration, taking as basis for discussion the text proposed by La Via Campesina (Human Rights Council 2012), with some adjustments to improve the structure and make it more consistent with UN language (Claeys 2012b).

At the first session of the working group, in July 2013, experts were invited to discuss various aspects of the proposed Declaration, and states had the opportunity to express their views (Human Rights Council 2014). On 12 November 2014, an informal consultation was held during which states and civil society participants shared their hopes about and objections to the process. Statements by La Via Campesina, the International Federation of Rural Adult Catholic Movements (FIMARC), the World Forum of Fisher People (WFFP), the International Union of Food Workers (IUF), CETIM and FIAN, all insisted on the need to ensure that the instrument protects not only peasants but all people working in rural areas from human rights violations. The importance of guaranteeing access to resources was similarly highlighted in all contributions as key to the existence and preservation of rural livelihoods. At the second session, which was held in February 2015, a new draft Declaration was presented by Ambassador Angelica Navarro of Bolivia, with a view to overcome opposition by some HRC member states. In order to do this, the new draft uses agreed language wherever possible, i.e. it builds on recent developments in international human rights law, as well 
as advances in other relevant international fora, such as the Committee on World Food Security, to formulate the new rights (to land, seeds, decent livelihoods) listed in the Declaration (Golay 2015). Negotiations are expected to continue in the years to come.

The assertion of new rights to resources is likely to constitute a stumbling block in the negotiations. For La Via Campesina, the rights to land, seeds, biodiversity and fair prices are the four central elements of the Declaration. For states reluctant to recognize new human rights for peasants, such as the European Union member states or the United States, the proposed right to land and right to seeds are amongst the most controversial, because of the collective nature of the rights claimed, because their indeterminate content departs from existing standards, and because of the challenges that their implementation would represent These rights have also been attacked for being associated with and imposing a certain type of development model (Golay 2013).

\section{Land Issues at the Committee on World Food Security}

In parallel, La Via Campesina has invested new arenas of global governance, such as the Committee on World Food Security (CFS), to actively contribute to the development of new international standards related to land issues, to a large extent grounded in human rights (McMichael 2014). Since its reform in 2009, the CFS has emerged as a central policy platform at the United Nations to address issues of food security, agriculture and nutrition. The CFS is an interesting arena due to the alternative governance model it offers (McKeon 2011 ; Duncan and Barling 2012) : It includes as members not only states, but also international financial institutions, relevant international organizations, the private sector, foundations and civil society.

The CFS represents a new institutional space within which peasant social movements can formulate their claims. Through the "civil society mechanism" $(\mathrm{CSM})^{9}$, La Via Campesina has act-

9. The Civil Society Mechanism (CSM) operates in an autonomous and self-organized fashion, and ensures the participation of 11 constituencies (small farmers, fisherfolk, landless, urban poor, agricultural workers, women, youth, indigenous peoples, consumers and NGOs) from 17 different sub-regions, according to specific procedures. La Via Campesina sits in a number of working groups, where themes such as land, agricultural investment, gender or nutri- ively participated in 2011-12 in the negotiations of Voluntary Guidelines on Responsible Governance of Tenure of Land, Fisheries and Forests in the Context of National Food Security (VGGT). It has also been heavily involved in discussions in 2013-14 on the development of Principles for Responsible Investment in Agriculture and Food Systems ("rai"), following the refusal by the CFS to adopt the Principles for Responsible Agricultural Investment (PRAI) developed by the World Bank, IFAD, UNCTAD and FAO in response to the phenomenon of land grabbing.

Most members of the Civil Society Mechanism positively assess progress made so far within the CFS, despite the fact that debates are often perceived as too technical and disconnected from on the ground realities. To many, participation in the negotiations on the VGGT demonstrated that civil society involvement in international standard setting can make a difference, as it enabled the recognition of the "legitimate tenure rights" of rural communities over the lands and territories they depend on for their livelihoods (Paoloni and Onorati 2014). According to the VGGT, states should recognize and respect these rights, including informal and customary rights, and protect land rights holders in the context of land transfers, large-scale investments in land, and programmes designed to adapt to and mitigate the impacts of climate change, in order to limit speculation, land concentration, and forced evictions. States should also facilitate land reform processes where necessary (Committee on World Food Security (CFS) 2012). Civil society efforts are now turning to the implementation of the VGGT in national contexts, with the assistance of the FAO, notably through the setting up of national, inclusive and participatory multi-stakeholder dialogue platforms. How the VGGT are implemented and interpreted in the years to come (Monsalve Suárez 2012) will determine if and whether the development of new international standards on land tenure has a positive impact on land tenure security on the ground.

Participation in the rai process, however, proved less successful. In the initial phase of the negotiations, civil society participants felt satisfied that they were able to use the process to promote an alternative development vision, grounded in peasant-based agroecological production systems and local food systems and markets, and to reframe

tion have been discussed. 
the terms of the debate by emphasizing that smallholder farmers themselves were the main investors, and should be recognized as such ${ }^{10}$. When the rai principles were finally adopted, however, at the 41st session of CFS on October 15,2014 , civil society participants walked out in protest, complaining that the principles failed to recognize the central role of small-scale producers and workers, instead placing the emphasis on facilitating large-scale investment. Members of the Civil Society Mechanism also regretted that the principles failed to acknowledge that different production systems have different environmental impacts, failed to offer protection against land, water and resource grabbing, and were not sufficiently grounded in international human rights standards (Civil Society Mechanism 2014). In short, the document appears to be about investment but avoids really tackling it (Müller and McMichael 2014). The principles, however, confirm the recognition of, and importance of respecting, legitimate tenure rights.

\section{Towards a Right to Land and Territory in International Law ?}

Progress so far and ongoing discussions on land issues, both within the Human Rights Council and the Committee on World Food Security, suggest the existence of a window of opportunity for the recognition of a new "human right to the land" (Künnemann and Monsalve Suárez 2013 ; De Schutter 2010a). The idea has made some notable advances in recent years. In its 2007 report to the Human Rights Council, the then Special Rapporteur on the right to housing, Miloon Kothari, recommended that the right to land be recognized in international law. The former Special Rapporteur on the Right to Food, Olivier De Schutter, in its 2010 report to the General Assembly of the United Nations recommended that international human rights bodies consolidate the right to land and clarify "the issue of land as a human right" (De Schutter 2010b, para. 43 (d)). The Rapporteur also called on states to implement land redistribution programmes wherever there is a high degree of land ownership concentration (De Schutter 2010b, para. 42 (c)).

Following intense internal discussions, FIAN International has also called for the formal

10. This assertion is based on the author's participation in the initial phase of the negotiation process of new principles for responsible agriculture investment at the CFS. recognition of a right to land (FIAN 2009), which the organization defends as a necessary response to land grabbing ${ }^{11}$. For FIAN, the explicit recognition of a right to land would enable questioning the legal doctrines inherited from the colonial era (which grant states the almost absolute power to dispose of the soil and do not effectively protect informal or customary land rights), and questioning political reforms to promote the privatization and commodification of the land such as titling programmes (Künnemann and Monsalve Suárez 2013, 130-131). The new right to land would be defined as the "right of every human being to access - individually or in community - local natural resources in order to feed themselves sustainably, to house themselves and to live their culture". It is not framed as a right to property and it does not refer to rights to buy or sell land, nor it is a right to make profit with land; it is limited to its use for communities and individuals feeding themselves and nurturing their cultures; it does not provide a right to far away land : the lands meant under the right to land are local (Künnemann and Monsalve Suárez 2013, 132).

The emergence of the "right to land and territory" is particularly interesting to study because it highlights the role of transnational peasant movements as "makers of legal change" (Rajagopal 2003, 167). Acknowledging the influence that the rights-based claims advanced by $\mathrm{La}$ Via Campesina activists have had on the various frames used by her organization, a member of the International Secretariat of FIAN, goes as far as arguing that : "the right to land itself could be the result of the interaction and mutual influence between the right to food network and the food sovereignty movement" 12 .

If it could be argued that UN Special Procedures and international human rights organizations such as FIAN have defended a new right to land in response to social movements' claims, it is interesting to note that the institutionalization of a new "right to land and territory" (beyond the land component the Declaration of the rights

11. The pursuit of this objective explains the active participation of FIAN in the process of developing Voluntary Guidelines on the tenure of land, both in the organization of consultations with civil society and in the negotiations themselves. It is also consistent with FIAN's decision to support the La Via Campesina in the negotiation of a draft Declaration of the rights of peasants at the Human Rights Council.

12. Interview, 23 June 2009. 
of Peasants) has not been a priority for peasant movements. In order to defend access to land and control over territories, La Via Campesina has mostly sought to mobilize collective action repertoires (Tilly 1986) that strengthen its ability to act as a social movement (P. Rosset and Martinez 2005), rather than use institutional repertoires. The GCAR, for example, has not engaged with many institutions beyond some individuals and departments within the FAO and IFAD (Borras 2008).

\section{Non-Institutional Strategies : the Defense of Lands and Territories}

Struggles led by La Via Campesina over recent years have relied more and more on oppositional and defensive strategies. They rely on social change "from below", rather than on institutional change (Claeys 2014). Such strategies focus on grassroots mobilization and reinforcing local food sovereignty practices, mainly through the conversion to agroecology (Altieri, Funes-Monzote, and Petersen 2011 ; P. M. Rosset and Martínez-Torres 2012 ; P. Rosset 2011 ; Holt-Gimenez (ed.) 2010) and the development of alternative food networks (Lamine 2005; Holloway and al. 2007 ; Maye and Kirwan 2010 ; Chiffoleau 2009 ; Brunori, Rossi, and Guidi 2012 ; Renting, Marsden, and Banks 2003). They are characterized by a strong distrust of the capacity of state institutions to produce social change and are characterized by a preference for sub-political forms of action (Scott 2008). Their primary purpose is to "reclaim control" through a focus on alternative production and consumption practices as a way to enact creative new forms of policy (Sherwood and al. 2013). The following excerpt from the 2007 Nyeleni Forum provides a good insight into this increasingly resonant collective action frame :

"We will fight against the corporate control of the food chain by reclaiming control over our territories, production, markets and the ways we use food."

(Nyeleni Forum synthesis report 2007).

\section{Reclaiming Control over Lands and Territories}

The concept of territory plays an increasingly important role in these multifaceted struggles aimed at reclaiming control. The defense of territories has long been at the heart of indigenous peoples resistance (Daes 2001, 12). What is new is the growing resonance of the concept of territory in the La Via Campesina movement, and the food sovereignty movement at large, both North and South. As expressed by this activist member of the Confédération paysanne in France : "How to reclaim our territories? Occupy the space? This is what is at stake." ${ }^{13}$ The recognition of indigenous peoples "rights to their lands, territories and resources", embodied in the 2007 UN Declaration on the Rights of Indigenous Peoples, is likely to have created such a new framing opportunity. Indeed, legal developments often offer new frames for social movements to deploy (Bereni and Chappe 2011, 27).

The notion of territory runs counter the capitalist transformation of the local into a "non-place" (van der Ploeg 2008, 269), it helps rethink the organization of our food system in terms of interconnected territorial units. In Guatemala, where the World Bank uses "territorial restructuring" to facilitate control over land and labour and enable the development of foreign-based extractive industries, indigenous acts of "territorial resistance" open spaces and places for "territorial sovereignty" (Holt-Giménez 2007). In the European context, the French term "terroir" describes a particular and vital relationship between a place or a specific region, quality products, producers and consumers. The terroir, according to Italian activist Carlo Petrini of the Slow Food movement is a "combination of natural factors (soil, water, slope, height above sea level, vegetation, microclimate) and human ones (tradition and practice of cultivation) that gives a unique character to each small agricultural locality and the food grown, raised, made, and cooked there" (Petrini 2001, 8). The territory appears as an entity representing more than the sum of the material resources it contains. It embodies a story, the relationship to a place, a commitment to a social and cultural context, as exemplified by the use of the notion of territory in urban land rights struggles (Sauer 2012) and "right to the city" movements (Harvey 2008), GM-free regions ${ }^{14}$ in Europe and GM-free territories in Costa-Rica ${ }^{15}$ and elsewhere, or food

$\overline{13 .}$ Peasant woman, Confédération paysanne, General Assembly, Montreuil, 4 May 2010.

14. http://www.gmo-free-regions.org/gmo-free-regions/ maps.html

15. http://seedfreedom.in/manifesto-in-defense-of-gmfree-territories/ 
standards developed from below (Friedmann and McNair 2008).

Based on these different sources of inspiration, the LVC movement is seeking to articulate notions of land and territory in a way that not only captures evolving peasant representations and practices but also incorporates the ongoing struggles of other (potentially) allied social groups, and functions as a powerful frame. The articulation of land and territory represents a challenge at numerous levels : the diversity of social actors and the various relations that different categories of land users have to land, territory and space ; the important variations that exist among local, cultural and historical contexts ; and the distinct levels of recognition of the rights of various groups (and various notions) in international human rights law. For example, the principle of free, prior and informed consent (FPIC) that has been recognized for Indigenous Peoples, is increasingly seized by other groups to defend their land against appropriation. The proposal to extend FPIC to rural communities was made during the negotiations of Voluntary Guidelines on the Governance of Tenure of Land, Fisheries and Forests, at the CFS, notably by the UN Special Rapporteur on the right to food. Yet, such a demand was not supported by indigenous peoples' representatives, who feared that this would weaken the implementation and defense of their granted rights.

Such an articulation will also need to move beyond the stereotypical connotations associated with land and territory. As shown by Sauer, if territories tend to be associated with notions of self-determination and autonomy, and lands tend to be seen as productive resources, many lands have symbolic and social dimensions and are increasingly seen as central to achieving peasant autonomy $^{16}$, while not all territories are traditional nor free from farming/exploitation for income generating purposes (Sauer, 2012). Similarly, the use of the term "territories" tends to be associated with resistance, whereas a growing body of literature on land rights in Asia, where palm oil development has seriously encroached on indigenous land, shows that the "resistance framework" is insufficient to analyze the complex dynamics at stake, including intra-community divisions, ambivalent

16. Land is increasingly seen as necessary to ensure peasant autonomy, notably through the conceptual work developed by Jan Douwe Van der Ploeg, as emphasized by Edelman (Edelman 2013). relations towards the state, and eagerness of some community members to enter business ventures or reap the benefits of such opportunities (Idrus, 2010, 100 ; Barney, 2004).

The ongoing dialogue between peasants and various other rural constituencies has already generated a new conception of agrarian reform from a territorial (and food sovereignty) perspective, according to LVC support staff and researcher Peter Rosset. Such a conception seeks to ensure that agrarian reform does not truncate the rights of other users of the land, and emphasizes that the "purpose" of land and territory is "reconstructing and defending community". A number of open questions still need to be addressed, however, such as how to address patriarchy and how best to advance women's rights (through communal or individual land rights), which mode of tenure is best able to resist appropriation, and how to build self-determination and autonomy from that perspective (Rosset 2013).

\section{Which Reference Frame for Future Land Struggles?}

In recent years, La Via Campesina member organizations have faced the arrival of new issues on the international agenda, such as the 2007-08 global food crisis, reinvestment in agriculture, climate change, and land grabbing. In this context, "land is becoming the new common denominator" (in the words of an activist from Habitat International Coalition interviewed at the 2009 World Summit for Food Security), and the "food sovereignty" frame needs to make more room for land rights issues. At the same time, the "right to agrarian reform" frame is losing resonance, despite efforts to give it a renewed meaning. As emphasized by a member of the Secretariat of FIAN International I interviewed, "farmer organizations increasingly use the concept of territory", especially in their "struggles against megaprojects", but "the concept of agrarian reform does not speak to indigenous peoples", especially as they "may be adversely affected by the redistributive land reforms" ${ }^{17}$. The demand for agrarian reform seems less appealing and appropriate to the current context, although it remains important. As pointed out by Borras and Franco, land reform is primarily targeted at the redistribution of already privatized resources, as in the case of

17. Interview, 24 June 2009. 
the latifundia in Latin America. The contemporary wave of land grabbing, to the contrary, constitutes an attack on "non-private" lands, because they take place where the land has been redistributed (e.g. Brazil, Mozambique, the Philippines and India) or in areas that are not covered by private institutional arrangements (such as public lands, public or communal)(S. Borras and Franco 2012, 5).

Will La Via Campesina, which just celebrated its $20^{\text {th }}$ anniversary, succeed in elaborating a new and potent frame for land struggles in the years to come? To resonate, this frame will need to manage the articulation of a) local, national and global struggles over the land, b) peasant, other rural, indigenous and urban claims on the land, and c) institutional and sub-political land struggles? Two broad categories of frames food sovereignty and peasants' rights - appear to coexist at the moment, from which the future organizational frame for land struggles is likely to emerge. While it is difficult to anticipate the extent to which these frames will resonate with other constituencies engaged in agrarian struggles, it appears at this stage that both the "right to land" and the "land sovereignty" frames could potentially become powerful in the future, though for different reasons.

On one hand, the "food sovereignty frame", which has played a key role in the emergence and consolidation of the LVC movement, could evolve so as to incorporate increasingly important land struggles. Efforts to link agrarian reform and food sovereignty have already been made (Rosset 2013), as illustrated by some frames used by the movement, such as "agrarian reform in the context of food sovereignty" (International Planning Committee for Food Sovereignty (IPC) 2006) or "agrarian reform-based food sovereignty" (Borras 2008). This frame could be invigorated by the proposal made by Borras and Franco ${ }^{18}$ to frame land claims in terms of "land sovereignty" in order to unify demands (for example across North and South) and integrate the "notions of space, ecology, territory, identity and belonging in a way that is both sustainable and accounts for access to, use of, and control over land" (S. Borras and Franco

18. The authors place land sovereignty within the rights master frame. They define land sovereignty as "the right of working peoples to have effective access to, use of, and control over land and the benefits of its use and occupation, where land is understood as resource, territory, and landscape". See http://www.tni.org/paper/land-sovereignty-alternative.
2012 , 6). Such a frame could become powerful if it succeeds in incarnating what McMichael has called the "emergent ontology of land sovereignty" that is "dedicated to the restoration of natural and social rights to reproduce humanity adequately and ecologically", and, indeed, in taking us "beyond the era of nation-state building, where counter-movements were concerned with labour, gender, and civil rights in the modern state" (McMichael 2014, 50, 52).

On the other hand, the "peasants' rights" frame could gain support and resonance within the movement and beyond, if negotiations on an International Declaration on the Rights of Peasants at the UN are seized as an opportunity to generate serious and wide-ranging public debate on control over natural resources. This frame could become particularly powerful if the emerging "right to land and territory" becomes recognized, with the support of the human rights community, as a universal human right. Not only could the right to land and territory embody the symbolic meanings carried by La Via Campesina's "right to produce" and FIAN's "right to feed oneself', but it could also establish itself as a way for local and national movements engaged in struggles to defend and control lands and territories, to re-establish a political limitation on "absolute private property” (Vergara-Camus 2012, 1142, 1146).

\section{References}

Alston, Phillip. 1984. "Conjuring up New Human Rights : A Proposal for Quality Control." The American Journal of International Law 78 (3): 607-21.

Altieri, Miguel, Fernando R. Funes-Monzote, and Paulo Petersen. 2011. "Agroecologically Efficient Agricultural Systems for Smallholder Farmers : Contributions to Food Sovereignty." Agronomy for Sustainable Development (INRA and Springer-Verlag).

Bachriadi, Dianto. 2009. "Land, Rural Social Movements and Democratisation in Indonesia." Transnational Institute.

Benford, R. D., and David A Snow. 2000. "Framing Processes and Social Movements : An Overview and Assessment." Annual Review of Sociology 26: 611-39.

Bereni, Laurence, and Vincent-Arnaud Chappe. 2011. "La Discrimination, de La Qualification 
Juridique À L'outil Sociologique.” Politix, no. 94 (February) : 7-34.

Bernstein, Henry. 2010. Class Dynamics of Agrarian Change. Agrarian Change and Peasant Studies. Initiatives in Critical Agrarian Studies, Fernwood Publishing and Kumarian Press.

Bob, Clifford. 2010. The International Struggle for New Human Rights. University of Pennsylvania Press.

Borras, Saturnino. 2008. "La Vía Campesina and Its Global Campaign for Agrarian Reform." Journal of Agrarian Change 8 (2-3) : 258-89.

Borras, Saturnino, and Jennifer C. Franco. 2012. "A 'Land Sovereignty' Alternative? Towards a Peoples' Counter-Enclosure (Discussion Paper).” TNI Agrarian Justice Programme.

Brunori, Gianluca, Adanella Rossi, and Francesca Guidi. 2012. "On the New Social Relations around and beyond Food. Analysing Consumers' Role and Action in Gruppi Di Acquisto Solidale (Solidarity Purchasing Groups)." Sociologia Ruralis 52 (1) : 1-30.

Bullard, Nicola, and Tadzio Müller.2012."Beyond the 'Green Economy': System Change, Not Climate Change?." Development 55 (1) : 54-62.

Chiffoleau, Yuna. 2009. "From Politics to CoOperation : The Dynamics of Embeddedness in Alternative Food Supply Chains." Sociologia Ruralis 49 (3) : 218-35.

Civil Society Mechanism. 2014. "Civil Society Statement on Rai | PAN AP.” October 15. http:// www.panap.net/campaigns/land-food-rights/ international-advocacy-and-instruments/2498.

Claeys, Priscilla. 2012a. "Vers Des Alternatives Au Capitalisme Néolibéral Par Une Conception Alternative Des Droits Humains? L'expérience Des Organisations Paysannes.” In Le Courage Des Alternatives (Christoph Eberhard Ed.), Cahiers d'Anthropologie du droit. Laboratoire d'anthropologie juridique de Paris UMR de droit comparé - Paris I, 103-20. Paris : Karthala.

Claeys, Priscilla. 2012b. "The Creation of New Rights by the Food Sovereignty Movement : The Challenge of Institutionalizing Subversion." Sociology 46 (5) : 844-60.

Claeys, Priscilla. 2014. “Vía Campesina’s Struggle for the Right to Food Sovereignty : From Above or From Below?" In Rethinking Food Systems.
Structural Challenges, New Strategies, and the Law (Lambek, Claeys, Brilmaeyer and Wong, Eds). Springer US.

Committee on ESCR. 1999. "General Comment 12. The Right to Adequate Food (Art.11). (E/C.12/1999/5)." May 12.

Committee on World Food Security (CFS). 2012. "Voluntary Guidelines on the Responsible Governance of Tenure of Land, Fisheries and Forests in the Context of National Food Security." FAO, United Nations.

De Schutter, Olivier. 2010a. "The Emerging Human Right to Land." International Community Law Review 12 (3) : 303-34.

De Schutter, Olivier. 2010b. "Report of the Special Rapporteur on the Right to Food Presented to the 65th General Assembly of the United Nations [A/65/281], 'Access to Land and the Right to Food." United Nations.

De Schutter, Olivier. 2011. "How Not to Think about Land-Grabbing : Three Critiques of Large-Scale Investments in Farmland." Journal of Peasant Studies 38 (2) : 249-79.

Desmarais, Annette Aurélie. 2008. La Via Campesina, Une réponse paysanne à la crise alimentaire. Montréal : Ecosociété.

Duncan, Jessica, and David Barling. 2012. "Renewal through Participation in Global Food Security Governance : Implementing the International Food Security and Nutrition Civil Society Mechanism to the Committee on World Food Security." International Journal of Sociology of Agriculture and Food 19 (2) : 143-61.

Edelman, Marc. 2013. "What Is a Peasant? What Are Peasantries? A Briefing Paper on Issues of Definition. Prepared for the First Session of the Intergovernmental Working Group on a United Nations Declaration on the Rights of Peasants and Other People Working in Rural Areas, Geneva, 15-19 July 2013." http://www. ohchr.org/Documents/HRBodies/HRCouncil/ WGPleasants/Edelman.pdf.

Elias, Juanita. 2010. "Transnational Migration, Gender, and Rights : Advocacy and Activism in the Malaysian Context." International Migration 48 (6) : 44-71.

Fairhead, James, Melissa Leach, and Ian Scoones. 2012. "Green Grabbing : A New Appropriation 
of Nature?" Journal of Peasant Studies 39 (2) : 237-61.

Fakih, Mansour, Toto Rahardjo, and Michel Pimbert. 2003. "Community Integrated Pest Management in Indonesia. Institutionalising Participation and People Centred Approaches." IEED and IDS.

FIAN. 2009. "Recognize Land as a Human Right. Sellout of Agricultural Lands Will Aggravate Food Crisis (press Release)." FIAN. December 10. http:// www.fian.org/news/press-releases/recognize-landas-a-human-right-sellout-of-agricultural-landswill-aggravate-food-crisis/?searchterm=access $\% 20$ to\%20land\%20resources.

Friedmann, Harriet, and Amber McNair. 2008. "Whose Rules Rule? Contested Projects to Certify 'Local Production for Distant Consumers." Journal of Agrarian Change 8 (2 and 3) : 408-34.

Golay, Cristophe. 2013. "Legal Reflections on the Rights of Peasants and Other People Working in Rural Areas. Briefing Paper Prepared for the First Session of the Working Group on the Rights of Peasants and Other People Working in Rural Areas, Geneva, 15-19 July 2013.” Geneva Academy.

Golay, Cristophe. 2015. "Negotiation of a United Nations Declaration on the Rights of Peasants and Other People Working in Rural Areas. InBrief No. 5." Geneva Academy.

Harvey, David. 2008. "The Right to the City." New Left Review 53 (October) : 23-40.

High Level Panel of Experts on Food Security and Nutrition (HLPE). 2011. "Land Tenure and International Investments in Agriculture." Committee on World Food Security.

Holloway, Lewis, Moya Kneafsey, Laura Venn, Rosie Cox, Elizabeth Dowler, and Helena Tuomainen. 2007. "Possible Food Economies : A Methodological Framework for Exploring Food Production-Consumption Relationships." Sociologia Ruralis 47 (1) : 1-19.

Holt-Giménez (ed.), Eric. 2010. "Linking Farmers' Movements for Advocacy and Practice." Journal of Peasant Studies 37 (1) : 203-36.

Holt-Giménez, Eric. 2007. “Development Report No 16: LAND - GOLD - REFORM The Territorial Restructuring of Guatemala's Highlands." Food First/Institute for Food and Development Policy. http://www.foodfirst.org/en/node/1770.
Hull, Kathleen E. 2001. "The Political Limits of the Rights Frame : The Case of Same-Sex Marriage in Hawaii." Sociological Perspectives 44 (2) : 207-32.

Human Rights Council. 2012. "Resolution on the Promotion of the Human Rights of Peasants and Other People Working in Rural Areas (A/ HRC/21/L.23).” United Nations.

Human Rights Council. 2014. "Report of the Open-Ended Intergovernmental Working Group on a Draft United Nations Declaration on the Rights of Peasants and Other People Working in Rural Areas. Chairperson-Rapporteur : Angélica C. Navarro Llanos (A/HRC/26/48).”

Idrus, Rusaslina. 2010. "From Wards to Citizens : Indigenous Rights and Citizenship in Malaysia." PoLAR : Political and Legal Anthropology Review 33 (1) : 89-108.

International Planning Committee for Food Sovereignty (IPC). 2006. "For a New Agrarian Reform Based on Food Sovereignty! Final Declaration of the 'Land, Territory and Dignity' Forum (Porto Alegre).”

International Planning Committee for Food Sovereignty (IPC). 2008. "No More Failuresas-Usual! Civil Society Statement on the World Food Emergency (Rome).”

Israël, Liora. 2003. "Faire émerger le droit des étrangers en le contestant, ou l'histoire paradoxale des premières années du GISTI.” Politix 16 (62): 115-43.

Keck, Margaret, and Kathryn Sikkink. 1998. Activists Beyond Borders : Advocacy Networks in Transnational Politics. Ithaca : Cornell University Press.

Konsorsium Pembaruan Agraria KPA. 2013. "UN Declaration on The Human Rights of Peasants Can Encourage Implementation of Agrarian Reform in Indonesia." April. http://www. kpa.or.id/?p=1516\&lang=en.

Künnemann, Rolf, and Sofía Monsalve Suárez. 2013. "International Human Rights and Governing Land Grabbing : A View from Global Civil Society." Globalizations 10 (1): 123-39.

Lamine, Claire. 2005. "Settling Shared Uncertainties : Local Partnerships Between Producers and Consumers." Sociologia Ruralis 45 (4): 324-45.

Margulis, Matias E., Nora McKeon, and Saturnino M. Borras. 2013. "Land Grabbing and 
Global Governance : Critical Perspectives." Globalizations 10 (1) : 1-23.

Maye, D., and James Kirwan. 2010. "Alternative Food Networks.” Sociopedia, ISA.

McAdam, Doug. 1990. Freedom Summer. Oxford University Press, USA.

McKeon, Nora. 2011. "Global Governance for World Food Security : A Scorecard Four Years After the Eruption of the 'Food Crisis." Heinrich Böll Foundation.

McMichael, Philip. 2014. "Rethinking Land Grab Ontology.” Rural Sociology, 79 (1): 34-55.

Monsalve Suárez, Sofia. 2012a. "The Human Rights Framework in Contemporary Agrarian Struggles." Journal of Peasant Studies, 1-52.

Monsalve Suárez, Sofia. 2012b. "The Recently Adopted Guidelines on the Responsible Governance of Tenure of Land, Fisheries and Forests: A Turning Point in the Global Governance of Natural Resources." Right to Food and Nutrition Watch, 37-43.

Mooney, Patrick H., and Scott A. Hunt. 1996. "A Repertoire of Interpretations : Master Frames and Ideological Continuity in U.S. Agrarian Mobilization." The Sociological Quarterly 37 (1): 177-97.

Müller, Birgit, and Philip McMichael. 2014. "The Land-Grab Trap: Is There a Will to Govern Global Land Grabbing? | FocaalBlog." Focaal. September 19. http://www.focaalblog. com/2014/09/19/philip-mcmichael-birgitmuller-the-land-grab-trap-is-there-a-will-togovern-global-land-grabbing/.

Nash, Kate. 2012. "Human Rights, Movements and Law : On Not Researching Legitimacy." Sociology 46 (5): 797-812.

Newell, Peter, and Joanna Wheeler. 2006. Rights, Resources and the Politics of Accountability. Claiming Citizenship. London and New York: Zed Books Ltd.

Nyéléni Food Sovereignty Forum. 2007a. "Synthesis Report. Nyéléni Forum for Food Sovereignty (2007).”

Nyéléni Food Sovereignty Forum. 2007b. "Declaration of Nyéléni."

Paoloni, Lorenza, and Antonio Onorati. 2014. "Regulations of Large-Scale Acquisitions of
Land : The Case of the Voluntary Guidelines on the Responsible Governance of Land, Fisheries and Forest." The Law and Development Review.

Petrini, Carlo. 2001. Slow Food: The Case for Taste. New York : Columbia University Press.

Pleyers, Geoffrey. 2010. "The Global Justice Movement." Globality Studies Journal, no. 19 (July).

Plummer, Ken. 2006. "Rights Work. Constructing Lesbian, Gay and Sexual Rights in Late Modern Times." In Rights : Sociological Perspectives (Morris L. Ed), 152-67. Routledge.

Rajagopal, Balakrishnan. 2003. International Law from Below : Development, Social Movements, and Third World Resistance. Cambridge University Press.

Reese, Ellen, and Garnett Newcombe. 2003. "Income Rights, Mothers' Rights, or Workers' Rights ? Collective Action Frames, Organizational Ideologies, and the American Welfare Rights Movement." Social Problems 50 (2): 294-318.

Renting, Henk, Terry K. Marsden, and Jo Banks. 2003. "Understanding Alternative Food Networks : Exploring the Role of Short Food Supply Chains in Rural Development." Environment and Planning 35 (3): 393-411.

Rosset, Peter. 2011. "The Campesino-to-Campesino Agroecology Movement of ANAP in Cuba: Social Process Methodology in the Construction of Sustainable Peasant Agriculture and Food Sovereignty (authors Include: Braulio Machín Sosa, Adilén María Roque Jaime and Dana Rocío Ávila Lozano).” Journal of Peasant Studies 38 (1) : 161-91.

Rosset, Peter. 2013. "Re-Thinking Agrarian Reform, Land and Territory in La Via Campesina." Journal of Peasant Studies 40 (4) : 721-75.

Rosset, Peter, and Maria Elena Martinez. 2005. "Participatory Evaluation of La Vía Campesina." The Norwegian Development Fund and La Via Campesina.

Rosset, Peter, and Maria Elena Martínez-Torres. 2010. "La Vía Campesina: The Birth and Evolution of a Transnational Social Movement." Journal of Peasant Studies 37 (1): 149-75.

Rosset, Peter, and Maria Elena Martínez-Torres. 2012. "Rural Social Movements and Agroecology : Context, Theory, and Process." Ecology and Society 17 (3). http://www.ecologyandsociety.org/ vol17/iss $3 /$ art17/. 
Santos, Boaventura de Sousa, and César A. Rodríguez-Garavito. 2005. Law and Globalization from Below : Towards a Cosmopolitan Legality. New York: Cambridge University Press.

Sauer, Sérgio. 2012. "Land and Territory: Meanings of Land between Modernity and Tradition." Agrarian South: Journal of Political Economy 1 (1) : 85-107.

Scott, James C. 2008. Weapons of the Weak: Everyday Forms of Peasant Resistance. Yale University Press.

Sherwood, Stephen, Alberto Arce, Peter Berti, Ross Borja, Pedro Oyarzun, and Ellen Bekkering. 2013. "Tackling the New Materialities: Modern Food and Counter-Movements in Ecuador." Food Policy 41 (C) : 1-10.

Sieder, Rachel. 2011. "Emancipation' or 'regulation' ? Law, Globalization and Indigenous Peoples' Rights in Post-War Guatemala." Economy and Society 40 (2) : 239-65.

Stammers, Neil. 1995. "A Critique of Social Approaches to Human Rights." Human Rights Quarterly 17 (3): 488-508.

Tilly, Charles. 1986. La France Conteste. Fayard.

Transnational Institute. 2013. "Land Concentration, Land Grabbing and People's Struggles in Europe.”TNI Agrarian Justice Programme.

Valocchi, Steve. 1996. "The Emergence of the Integrationist Ideology in the Civil Rights Movement." Social Problems 43 (1) : 116-30.

Van der Ploeg, Jan Douwe. 2008. The New Peasantries: Struggles for Autonomy and Sustainability in an Era of Empire and Globalization. London and USA : Earthscan.

Vergara-Camus, Leandro. 2012. “The Legacy of Social Conflicts over Property Rights in Rural Brazil and Mexico : Current Land Struggles in Historical Perspective." Journal of Peasant Studies 39 (5): 1133-58.

Vía Campesina. 1996. "The Right to Produce and Access to Land. Food Sovereignty : A Future without Hunger (Statement at the Occasion of the World Food Summit, Rome, Italy)."

Vía Campesina. 1999. "Seattle Declaration: Take WTO out of Agriculture."

Vía Campesina. 2006. "Commentary on Land and Rural Development Policies of the World
Bank. Working Document. Global Campaign for Agrarian Reform." February 14. http:// viacampesina.org/en/index.php/main-issuesmainmenu-27/agrarian-reform-mainmenu36/83-commentary-on-land-and-rural-development-policies-of-the-world-bank2.

Vía Campesina. 2008a. "Declaration of Rights of Peasants, Women and Men." http://viacampesina.net/downloads/PDF/EN-3.pdf.

Vía Campesina. 2008b. "In the 60th Anniversary of the Universal Declaration of Human Rights, We Peasants Demand Our Own Convention. Final Declaration of International Conference on Peasants' Rights (Jakarta).”

Vía Campesina. 2008c. "Declaration of Maputo (Declaration of the 5 th International Conference of Via Campesina, Maputo, Mozambique).”

Vía Campesina. 2012. "Bukit Tinggi Declaration on Agrarian Reform in the 21st Century." July 14. http://viacampesina.org/en/index.php/ main-issues-mainmenu-27/agrarian-reformmainmenu-36/1281-bukit-tinggi-declarationon-agrarian-reform-in-the-21st-century.

Vía Campesina, and GRAIN. 2009. "Les Paysans et les Mouvements Sociaux disent non à l'accaparement des terres. Invitation à une conférence de presse et à une action symbolique (Rome).”

Vía Campesina Regional South East Asia and East Asia. 2002. "Peasant Rights. Droits Paysans. Derechos Campesinos." Vía Campesina.

Whiteside, Noel, and Alice Mah. 2012. "Human Rights and Ethical Reasoning : Capabilities, Conventions and Spheres of Public Action." Sociology 46 (5): 921-35.

Windfuhr, Michael. 2000. "Agrarian Reform: A Human Rights Obligation. Paper Presented to the International Conference on Agrarian Reform and Rural Development (ICARRD) Tagaytay City, Philippines." FIAN International. 


\section{Working Papers parus en 2015 et en 2016}

Georges Corm, Christiane

Veauvy, Proche-Orient et conscience historique, entretien, FMSH-WP-2015-87, janvier 2015.

Dominique Boullier, Les sciences sociales face aux traces du big data ? Société, opinion et répliques, FMSH-WP-2015-88, février 2015.

Christian Walter, Les deux quantifications de la théorie financière. Contribution à une bistoire critique des modèles financiers, FMSH-WP-2015-89, février 2015.

Ernest Amoussou, Analyse hydrométéorologique des crues dans le bassin-versant du Mono en Afrique de l'Ouest avec un modèle conceptuel pluie-débit, FMSHWP-2015-90, avril 2015.

Sudip Chaudhuri, Premature Deindustrialization in India and Re thinking the Role of Government, FMSH-WP-2015-91, april 2015.

Guilhem Fabre, The Lions's Share, Act 2. What's Bebind China's Anti-Corruption Campaign?, FMSH-WP-2015-92, april 2015.

Viêt Anh CAO, Documents en caractères sino-vietnamiens aux Archives nationales d'outre-mer (France): une source riche en vestiges de l'histoire du Viêt Nam à l'époque coloniale (1875-1945), FMSH-WP-2015-93, avril 2015.
Marco Marin, Esprit public et marché éditorial au début de la Première République (17931795), FMSH-WP-2015-94, avril 2015.

Christian Walter, Jumps in financial modelling: pitting the Black-Scholes model refinement programme against the Mandelbrot programme, FMSHWP-2015-95, april 2015.

Andrea Lanza Un organicisme de la complexité. Notes pour un chapitre sur le socialisme et les sciences naturelles (France, première moitié du XIX $X^{e}$ siècle), FMSHWP-2015-96, juin 2015.

Vincent Duclos, Le design du monde. De McLuhan à Sloterdijk, vers une anthropologie de l'espace en devenir, FMSHWP-2015-97, juin 2015.

Mathias Grote, What could the 'longue durée' mean for the history of modern sciences?, FMSHWP-2015-98, june 2015.

Philippe Steiner, Comte, Altruism and the Critique of Political Economy, FMSH-WP-2015-99, GeWoP-8, june 2015.

Pierre Salama, Argentine, Brésil, Mexique entrent dans la tourmente. Quo vadis Amérique latine?, FMSH-WP-2015-100, juin 2015.

Ayşe Yuva, Die Historisierung der Philosophie in Deutschland und Frankreich nach Kant, FMSHWP-2015-101, october 2015.
Elisa Brilli, Mettre en image les deux cités augustiniennes (ms. Florence, BML, Plut. 12.17), FMSH-WP-2015-102, octobre 2015.

Julie Patrier, Les dépôts alimentaires dans les tombes d'Anatolie centrale au II ${ }^{e}$ millénaire av. J.-C., FMSH-WP-2015-103, octobre 2015.

Matthieu Renault, Préface à la révolution. C.L.R. James, lecteur de Melville, FMSHWP-2015-104, juillet 2015.

Yang Dongping, Enseignement supérieur, équité et société, FMSH-WP-2015-105, octobre 2015.

Olivier Galland, Un pacte implicite entre les générations pour le statu quo, FMSHWP-2015-106/GeWoP-9, novembre 2015.

Anais Albert, Consommation de masse et consommation de classe à Paris des années 1880 aux années 1920 : bilan d'une recherche, FMSH-WP-2016-107, janvier 2016.

Philippe Rousselot, Les forces spéciales américaines: vers une refondation?, FMSH-WP-2016-108, mars 2016.

Priscilla Claeys, The Right to Land and Territory: New Human Right and Collective Action Frame, FMSH-WP-2016-109, mars 2016

Retrouvez tous les working papers et les position papers sur notre site, sur hypotheses.org et sur les archives ouvertes halshs

http://www.fmsh.fr/fr/ressources/working-papers

http://halshs.archives-ouvertes.fr/FMSH-WP

http://wpfmsh.hypotheses.org 